\title{
The Application of Literary Components (Komsas) Materials in Teaching and Learning the Malay Language among Secondary School Students
}

\author{
Abdul Rasid Jamian ${ }^{1, *}$, Norfaizah Abdul Jobar ${ }^{1}$, Mohd Rashid Md Idris ${ }^{1}$, Arif Mohamed ${ }^{1}$, \\ Nur Farahkhanna Mohd Rusli ${ }^{1}$, Zamri Mahamod ${ }^{2}$ \\ ${ }^{1}$ Faculty of Languages and Communication, Universiti Pendidikan Sultan Idris, Tanjong Malim, Perak, Malaysia \\ ${ }^{2}$ Faculty of Education, Universiti Kebangsaan Malaysia, Bangi, Malaysia
}

Received July 6, 2020; Revised November 17, 2020; Accepted November 30, 2020

\section{Cite This Paper in the following Citation Styles}

(a): [1] Abdul Rasid Jamian, Norfaizah Abdul Jobar, Mohd Rashid Md Idris, Arif Mohamed, Nur Farahkhanna Mohd Rusli, Zamri Mahamod, "The Application of Literary Components (Komsas) Materials in Teaching and Learning the Malay Language among Secondary School Students," Universal Journal of Educational Research, Vol. 8, No. 12A, pp. 7547 - 7554, 2020. DOI: 10.13189/ujer.2020.082539.

(b): Abdul Rasid Jamian, Norfaizah Abdul Jobar, Mohd Rashid Md Idris, Arif Mohamed, Nur Farahkhanna Mohd Rusli, Zamri Mahamod (2020). The Application of Literary Components (Komsas) Materials in Teaching and Learning the Malay Language among Secondary School Students. Universal Journal of Educational Research, 8(12A), 7547 - 7554. DOI: 10.13189/ujer.2020.082539.

Copyright $\bigcirc 2020$ by authors, all rights reserved. Authors agree that this article remains permanently open access under the terms of the Creative Commons Attribution License 4.0 International License

\begin{abstract}
This study was conducted to identify the importance of using the literary components (KOMSAS) materials in teaching the Malay language among form four students. The study is focused on the perception of the students toward the literary components, the teachers' strategy in teaching KOMSAS, and the problems that arise during the teaching process. A total of 120 form four students from Chung Hua High School, Seremban, were chosen as the sample. The data are collected using the quantitative method through the five-point Likert scale questionnaires. The data are analyzed using the statistical software of SPSS Version 17.0 to determine the mean and standard deviation based on the indicator level of high, medium or low levels. The data are presented using the frequency and percentage of the specific items. The results showed that the students at the age of 16 and 17 have little or no interest in learning KOMSAS due to several factors. The pattern from the gathered results showed that students are only interested in specific genres of the KOMSAS, such as short stories. However, the students insisted on the additional KOMSAS materials in the Malay language syllabus since it has many lessons and values that could be learned. The study also found that the teachers are less sensitive in selecting appropriate strategies and activities, limiting students' participation in class, even the concept of
\end{abstract}

bestari teaching aids are already utilized.

Keywords Teaching Aids, Literary Components, Teaching and Learning of the Malay Language, Achievements, Motivation

\section{Introduction}

The application of the KOMSAS materials in teaching and learning the Malay language was introduced in March 2000. The subject then was revised after it was used in schools for a decade under close observation of the Integrated Curriculum Secondary School (KBSM) in 1987. The syllabus of teaching and learning KOMSAS was revised again in 2010, and it is based on the textual anthologies and novels used in the form four syllabus. It is stated in the Dokumen Standard Kandungan dan Pentaksiran (DSKP) in 2013, which mentioned that the literary components would remain the same and not changeable. The curriculum is revised as it is needed to fulfil the National Education Philosophy and to prepare the students in making them able to withstand the challenges of the $21^{\text {st }}$-century educational system. The 
adaptation of the literary component's materials into the Malay language is a good strategy in expanding students' potential equally from various aspects such as spiritual, physical, intellectual and emotional. It is also to ensure that students will absorb and apply the necessary values and lessons from the literature in becoming a good person.

Moreover, the usage of KOMSAS materials in the Malay language can enhance and strengthen the language proficiency of the students. Besides, literature also enables the students to be aware of the human values in holistic through reading and literary components. According to the learning outcomes of the Malay language, the students must be able to understand the informational knowledge skill, aesthetical and interpersonal, and it is shown that KOMSAS materials are suitable to be used as a method of teaching because it covers the language skills such as listening, speaking, reading and writing.

The usage of literary components in teaching and learning the Malay language is different from the actual literature teaching as there is no in-depth research; instead, it is only used as a stimulation for the students. According to Abdul Rasid Jamian \& Hasmah Ismail (2013) proposed that the teachers with a positive mindset and high confidence may lead the learning and teaching the Malay language process to become more creative and fun. They also acknowledged that teachers use multimedia in creating a fun teaching environment.

Significantly, it is an effort to make the Malay language to become one of the compulsory subjects that fulfil the goals of National Education Philosophy. The appropriate teaching materials are required to ensure that students are guided equally in various aspects. The usage of the KOMSAS materials in the teaching and learning process of the Malay language by the teachers must be given observation and attention so that positive feedback can be received from the students. The specific objectives of this research are to analyze the student's perception of the application of KOMSAS materials in teaching and learning the Malay language, to identify the strategies that are used by teachers in teaching and learning KOMSAS and to find out the problems that arise during teaching and learning KOMSAS.

\section{Problem Statement}

The KOMSAS literary components in learning and teaching the Malay language of form four students have been practically used for a long time. It has started with poems materials and later on using the prose materials. However, before the KBSM and the Standard Curriculum for Secondary Schools (KSSM) existed, the educational system did not have any textbooks that were acknowledged by the Ministry of Education to be used as a reference for teaching. The teacher had to independently search for materials, which resulted in different opinions and clashed with the learning outcomes of the Malay language. Generally, Nik Hassan Basri (2017) found out that the Malay language teachers find it hard to understand the needs of the KOMSAS materials in the learning and teaching process. It has caused that teachers teaching KOMSAS apply the same method to teach the Malay literature subject and do not have the confidence to teach the KOMSAS. Hence, this situation gives impacts on the students in learning KOMSAS.

This study was conducted as there is a necessity to identify the perception of students towards the KOMSAS implementation in Malay language subjects. One of the essential factors that acted as a catalyst to conduct this study which is the purpose of using Malay KOMSAS materials in teaching and learning. This factor must be considered because there are texts that were being used before have negative characteristics from the way the language is presented and its morality. Therefore, there is a need for this problem considered in determining the relevancy of the author's language in their writings. Chew Fong Peng (2019) stated that the KOMSAS were introduced for the Malay language because they are the reflection of the society's identities. It could be further strengthened by what Chew Fong Peng and Nurmaziah Majelan (2019) suggested that different races find that there is a visible difference in the execution of the unity element in education. Therefore, this study is conducted to determine whether the KOMSAS truly reflects on the reality of the multi races in Malaysia as the initial vision when KOMSAS is firstly introduced.

Besides, the strategy that is commonly used when teaching the subject is still not stable as teachers use the conventional methods and are less exposed to the use of online teaching aids (Zamri \& Nur Aisyah, 2011). This exposure to online teaching aids brings a lot of help in this current situation which the informational and communicational technology plays an essential role as the primary medium. Hence, teachers need to be skillful in online teaching. The use of computers as a teaching method opens up opportunities for students to study the KOMSAS independently, where teachers act as facilitators. However, does this method can improve the students' interest in learning the KOMSAS and act as a solution for students who lack interest and focus in class?

Teaching and learning KOMSAS has raised some issues about the learning situation, which is considered less effective and attracted students. The teaching process of teachers was found to be incapable of highlighting the implicit and explicit ideas in literary materials. Therefore, based on a study conducted by Zamri Mahamod \& Jamila Hassan (2018) stated that Malay language teachers should be exposed to problem-based solving (PBM) in their teaching and learning process. It will help their teaching and learning become more effective and much more enjoyable. It often happens when the teachers are only focused on specific themes, which are the themes of the current issues, the theme of social and community values, 
family themes, and the theme suggesting the strategies for the teachers to be more creative and innovative. According to Abdul Rasid Jamian et al. (2018), the teachers need to practice high-order thinking skills in teaching (Tee et al., 2020), especially in teaching short stories and novels. Therefore, students will also gain confidence in practising high-order thinking skills (Azid et al., 2019). In a study conducted by Norfaizah et al. (2020), it stated that effective learning is based on a specific theme where it makes them integrate their thinking systematically.

Therefore, based on the study that has been conducted, it can be concluded that the KOMSAS materials are suitable to be applied into the syllabus including the culture to cultivate good values for the students regardless of their background. However, the study found that the students face problems in learning KOMSAS such as text difficulties, time constraints, lack of motivation and literary exposure, lack of time to express feelings and opinions, as well as uninteresting teaching and learning process. According to Nurhamizah et al. (2018), students will understand the KOMSAS better if the materials exhibit good moral elements. This is very helpful for teachers to make research on the content of the text before using it in teaching and learning. KOMSAS materials aim to create an appreciation for the beauty of Malay literary arts and feel the excitement when the students read their works. According to Mohd Rashid Md Idris et al. (2020), they explained that a work has a character trait that shows the personality. Thus, it tells us that some materials have a connection in the students' lives. Therefore, teachers need to determine the appropriate teaching materials for students. The goal is quite challenging to achieve if there is a lack of materials used in KOMSAS teaching and learning process in the classroom. The existed problems can block the teaching goals of KOMSAS and should be given attention to by teachers as facilitators.

The teaching and learning goals of KOMSAS indicate a very high expectation to produce a generation that loves to read and is interested in the art of national heritage. Through the appreciation of literature, curriculum developers aim to bring a sense of pride in the beauty and uniqueness of language, mastering the linguistic aspects and able to create creative writing skill among the students.

\section{Significance of Research}

Teachers have a critical responsibility as guidance and mentors to their students. As a teacher, the interests of the students in their studies must be upheld more than other interests. This research aim is to study the perceptions of students, whether they are interested in learning KOMSAS or not. Thus, the lack of interest and phobia in learning literature will be the main factor in the decline of examination scores due to the students' performance in their class. This situation will also cause other problems during the KOMSAS teaching, and learning sessions as students will be less attentive and passive during teaching, not completing their homework and have no initiative to improve their self-performance.

Besides, it is hoped that through this research, the practice of teaching and learning the KOMSAS will be able to give a brief idea towards Malay language teachers on the importance of applying this syllabus. Teachers need to be attentive towards students so that they will not be left behind, and it is the teachers' responsibilities to understand and identify how to teach the subject creatively and confidently in any situation.

The findings from this research will be able to help in identifying the problem for the difficulty in understanding KOMSAS materials and also generate any suitable strategies. Besides, this research can contribute to giving benefits to the party involved in KOMSAS for Malay language subject for them to plan, organize, and set up a great strategy to ensure that students can improve and enhance their skills in the KOMSAS texts.

\section{Research Questions}

The objectives of this research that needs to be achieved are based on the following:

1. How far is the student's perception toward the application of KOMSAS materials in teaching and learning the Malay language?

2. What is the strategy that is used by teachers in teaching and learning the KOMSAS?

3. What are the problems that occur during the teaching and learning of the literary components?

\section{Research Methodology}

This study is a descriptive research that is conducted to explain the execution of the use of KOMSAS materials in the teaching and learning of the Malay language in secondary school.

\section{Research Design}

Research design is a process of data collecting procedure that aims to answer the research questions from the objective of the research. It is a research observation in a setting which involves form four students as its respondents. This study is conducted to gather information regarding the perception of students toward the literary components, the strategies used by teachers in the teaching and learning of the KOMSAS and problems that occur during the teaching and learning of the KOMSAS. The research design used by this study 
includes significant information gathering through the use of instruments such as five-point Likert scale questionnaires.

\section{Research Location}

This study was conducted in a secondary school which is the Chung Hua High School Seremban, Seremban, Negeri Sembilan. This study was held in that secondary school due to the distance of the place, and other complications did not occur during the study because of the support from the principal of the school.

\section{Population and Research Sampling}

In this study, the research sampling is using random sampling, whereby every member of the designated population has an equal opportunity to be chosen as the sample. According to Noraini (2010), this is the best method to use in gathering samples in a large size community or population. The use of random sampling in this research is adapted from Krejcie \& Morgan (1970) that come up with a table for determining sample from a given population. The total number of form four students is $\mathrm{N}=173$; the sample size consists of $\mathrm{S}=120$ respondents. The sample was selected from four classes which consist of form four students that have applied the latest literary components KOMSAS after the changes of the text anthology materials and novel.

\section{Research Instrument}

This study uses a set of questionnaires as its research instrument to collect the data. Commonly, social sciences research uses a specifically designated research instrument to gather data (Chua Yan Piaw, 2006). Therefore, in this research, the questionnaires have divided into four parts which are:

Part A: Respondents Demography.

Part B: Students' perceptions of the use of KOMSAS materials.

Part C: The strategies used by the teachers in the teaching of the KOMSAS in classrooms.

Part D: Problems that arise during the teaching of KOMSAS in the classroom.

\section{Data Analysis}

From the gathered information, the data will be analyzed based on several parts. The data were gathered from the questionnaires, which use the five-point Likert scale by selecting the provided number. The data are analyzed using the statistical software, which is SPSS 17.0 Version, to determine the mean and standard deviation level based on high, medium and low. Therefore, the score for the mean level of every category, as illustrated in Table 1 below.
Table 1. Score for each Mean Level

\begin{tabular}{|c|c|}
\hline Mean & Level \\
\hline $1.00-2.33$ & Low \\
\hline $2.34-3.67$ & Medium \\
\hline $3.68-5.00$ & High \\
\hline
\end{tabular}

Source: Durrishah Idrus (2004)

\section{Research Findings}

\section{Respondents Demography}

The respondents from this research consist of 120 form four students from the Chung Hua High School Seremban, Seremban. Analysis from Part A is presented in a table format that is illustrated based on frequency $(f)$ and percentage (\%). This research has involved 59 male students $(49.12 \%)$ and 61 female students $(50.83 \%)$. The total number of respondents is 115 students $(95.83 \%)$ are 16 years old, and 5 students $(4.17 \%)$ are 17 years old. The data also shows that only 6 students (5\%) show interests in learning the Malay language subject. The remaining students chose Mathematics $(23.33 \%)$ as their favourite subject and followed other subjects such as English (17.5\%), Accounting (15.83\%), Mandarin (15\%), Arts and Science shares the same percentage which is $(10 \%)$. The least favourite subject is History which was only chosen by 4 students (3.33\%).

The Students' Perceptions of the Application of KOMSAS Materials in Teaching and Learning the Malay Language

Based on Table 2 below, the total mean score for the students' perceptions towards the application of KOMSAS materials in teaching and learning the Malay language is $3.99(\mathrm{SD}=.53)$ shows that all the items are on a high mean level. The results from the study also show that the lesson learnt in the KOMSAS can be adapted as a guidance life shows a high mean level which is 4.23 $(\mathrm{SD}=.60)$. It is followed by the statement of the number of students that refer to the reference books in KOMSAS subject is $4.08(\mathrm{SD}=.49)$. Next, for the good lessons that can be learnt from the KOMSAS has a mean value of 4.03 $(\mathrm{SD}=.50)$. Subsequently, the mean value of 4.02 $(\mathrm{SD}=.49)$ is for the statement of students that show intersts in the specific genre in the KOMSAS text. The mean for the statement of students should be exposed to the literary materials in mastering the KOMSAS is 4.01 $(\mathrm{SD}=.54)$ and for the number of students read the KOMSAS texts because it has a variety of register has a mean of $3.97(\mathrm{SD}=.51)$. The mean level for including materials in the learning process becomes more interesting shows a mean of $3.95(\mathrm{SD}=.43)$. Meanwhile, for the statement of students need to study particular genre in KOMSAS text, and KOMSAS included as a part of the 
Malay language syllabus because of its exciting genres is $3.90(\mathrm{SD}=.56)$. The statement that shows the lowest mean is for the statement which students are becoming more skilled in writing due to the exposure in the Malay language syllabus with mean $3.89(\mathrm{SD}=.58)$.

Table 2. Students' Perceptions of the Application of KOMSAS Materials in Teaching and Learning the Malay Language

\begin{tabular}{|l|c|c|}
\hline \multicolumn{1}{|c|}{ ITEMS } & MEAN & $\begin{array}{c}\text { STANDARD } \\
\text { DEVIATION }\end{array}$ \\
\hline $\begin{array}{l}\text { Ilike a specific genre in the KOMSAS texts } \\
\text { anthology. }\end{array}$ & 4.02 & .49 \\
\hline $\begin{array}{l}\text { I study particular genres that are included in } \\
\text { the literary component texts. }\end{array}$ & 3.90 & .56 \\
\hline $\begin{array}{l}\text { The learning process becomes more } \\
\text { interesting with the use of KOMSAS } \\
\text { materials. }\end{array}$ & 3.95 & .43 \\
\hline $\begin{array}{l}\text { I read the KOMSAS texts because it has a } \\
\text { variety of register. }\end{array}$ & 3.97 & .51 \\
\hline $\begin{array}{l}\text { I refer to the reference book to master the } \\
\text { learning process of the KOMSAS. }\end{array}$ & 4.08 & .49 \\
\hline $\begin{array}{l}\text { Many good lessons can be learned from the } \\
\text { KOMSAS genre. }\end{array}$ & 4.03 & .50 \\
\hline $\begin{array}{l}\text { The good values in the KOMSAS can be } \\
\text { adapted as guidance in life. }\end{array}$ & 4.23 & .60 \\
\hline $\begin{array}{l}\text { I become more skilled in writing due to the } \\
\text { exposure to the Malay language syllabus. }\end{array}$ & 3.89 & .58 \\
\hline $\begin{array}{l}\text { KOMSAS has to be included as a part of the } \\
\text { Malay language syllabus because of its } \\
\text { exciting genres. }\end{array}$ & 3.90 & .56 \\
\hline $\begin{array}{l}\text { Students need to be exposed to literary } \\
\text { materials to master the KOMSAS in } \\
\text { learning the Malay language. }\end{array}$ & 4.01 & .54 \\
\hline $\begin{array}{l}\text { TOMN } \\
\text { maln }\end{array}$ & 3.99 & .53 \\
\hline
\end{tabular}

\section{Strategies Used by the Teachers in Teaching and Learning KOMSAS}

Based on Table 3 below, the total mean for strategies that are used by teachers in teaching and learning KOMSAS is $3.42(\mathrm{SD}=.86)$. It shows four statements with a medium mean, and two items have a high mean. Despite that, based on the statistical analysis, it is found out that the overall mean for Part $\mathrm{C}$ is lower than the total mean for Part B (refer to Table 3). The statement of a teacher preparing modules for KOMSAS has the highest mean of $3.76(\mathrm{SD}=.77)$. The statement regarding teachers apply group work activities based on KOMSAS genre has a mean of $3.74(\mathrm{SD}=.94)$. Then, for the statement teachers train the students to act based on KOMSAS genre, teachers use the bestari method during teaching KOMSAS, and teachers have creative approach in creating teaching materials have a low mean of 3.48 $(\mathrm{SD}=.89), 3.26(\mathrm{SD}=.87)$, and $3.24 \quad(\mathrm{SD}=.88)$ respectively. The lowest mean recorded and has the medium level is for teachers still use the traditional methods in teaching, and the learning process of KOMSAS is $3.01(\mathrm{SD}=.80)$.
Table 3. Strategies Used by Teachers in the Teaching and Learning Process of KOMSAS

\begin{tabular}{|l|c|c|}
\hline \multicolumn{1}{|c|}{ ITEMS } & MEAN & $\begin{array}{l}\text { STANDARD } \\
\text { DEVIATION }\end{array}$ \\
\hline $\begin{array}{l}\text { Teachers use traditional methods for teaching } \\
\text { and learning KOMSAS. }\end{array}$ & 3.01 & .80 \\
\hline Teachers prepare modules for KOMSAS. & 3.76 & .77 \\
\hline $\begin{array}{l}\text { Teachers use the bestari methods for teaching } \\
\text { KOMSAS. }\end{array}$ & 3.26 & .87 \\
\hline $\begin{array}{l}\text { Teachers apply group work activities based } \\
\text { on the KOMSAS genre. }\end{array}$ & 3.74 & .94 \\
\hline $\begin{array}{l}\text { Teachers have a creative approach to creating } \\
\text { teaching materials for KOMSAS. }\end{array}$ & 3.24 & .88 \\
\hline $\begin{array}{l}\text { Teachers teach students acting based on } \\
\text { genres in KOMSAS. }\end{array}$ & 3.48 & .89 \\
\hline \multicolumn{1}{|c|}{ TOTAL MEAN } & 3.42 & .86 \\
\hline
\end{tabular}

\section{Problems that Occurs during Teaching and Learning KOMSAS}

According to Table 4, the overall mean is 3.91 $(\mathrm{SD}=.55)$, which also shows that almost all items are at a high mean level. The item, which refers to students' no interest in KOMSAS because the teaching process is not interesting, has a high mean of $4.14(\mathrm{SD}=.52)$. It is followed by a mean of $4.04(\mathrm{SD}=.47)$ for the teaching process is not interesting because the teachers do not use the bestari method when using KOMSAS materials. Next, teachers use reference books due to time limitations have a mean value of $4.02(\mathrm{SD}=.48)$, whereas teachers feel pressured to finish the KOMSAS syllabus has a mean of $3.90(\mathrm{SD}=.49)$. Next, teachers that only use the textbooks for KOMSAS during teaching have a mean of 3.89 $(\mathrm{SD}=.46)$. Finally, teachers that only use the 'Chalk \& Talk' method when teaching and learning KOMSAS have recorded a medium mean level with a value of 3.42 $(\mathrm{SD}=.87)$.

Table 4. Problems that Occur during Teaching and Learning KOMSAS.

\begin{tabular}{|l|c|c|}
\hline \multicolumn{1}{|c|}{ ITEMS } & MEAN & $\begin{array}{c}\text { STANDARD } \\
\text { DEVIATION }\end{array}$ \\
\hline $\begin{array}{l}\text { I have no interest in KOMSAS because the } \\
\text { teaching process is not interesting. }\end{array}$ & 4.14 & .52 \\
\hline $\begin{array}{l}\text { The teaching process is not interesting } \\
\text { because the teachers do not use the bestari } \\
\text { method while teaching KOMSAS. }\end{array}$ & 4.04 & .47 \\
\hline $\begin{array}{l}\text { Teachers only use textbooks during the } \\
\text { teaching of KOMSAS. }\end{array}$ & 3.89 & .46 \\
\hline $\begin{array}{l}\text { Teachers replace the use of KOMSAS } \\
\text { materials with reference books due to time } \\
\text { limitations. }\end{array}$ & 4.02 & .48 \\
\hline $\begin{array}{l}\text { Teachers only use the 'Chalk \& Talk' method } \\
\text { in the teaching and learning process of } \\
\text { KOMSAS. }\end{array}$ & 3.42 & .87 \\
\hline $\begin{array}{l}\text { Teachers feel pressured to finish the } \\
\text { KOMSAS syllabus. }\end{array}$ & 3.90 & .49 \\
\hline \multicolumn{1}{|c|}{ TOTAL MEAN } & 3.91 & .55 \\
\hline
\end{tabular}




\section{Discussion and Summary}

This research has explained the findings of the student perceptions, strategies used by the teachers in the teaching of KOMSAS, and the problems that students encounter during the teaching and learning of KOMSAS. The data collected can be concluded that respondents either show less interest or no interest in learning KOMSAS materials. Results showed that only 6 students $(5 \%)$ are interested in the Malay language subject, and the students have not fully mastered the literary skills.

Based on the findings of the student's perception showed the lowest mean is the number of students that can write increased because of the KOMSAS exposure in the Malay language syllabus has a mean of $3.89(\mathrm{SD}=.58)$, which is only $8 \%$ of students strongly agree and $15.8 \%$ of students disagree and strongly disagree to this statement. Students are still less skilled in writing short story essays despite being given sufficient KOMSAS materials exposure because they do not fully master the literary aspect. Having no interest and phobia in learning the literary materials have become the main contributors to the decline in achievements and participation KOMSAS activities in the classroom.

This study was also able to determine that the students agreed that they have interests in the KOMSAS materials because the KOMSAS texts have various types of registers. However, almost half of the students disagreed with the use of registers in the KOMSAS genre. Referring to Mengintai Ruang Insaf poem, which is a part of the form four KOMSAS textbooks, Harga Remaja, respondents find it is hard to understand the meaning of the poem because the concept is not clear. Therefore, the choice of the texts that are to be used as a part of the syllabus should be more comfortable to be translated and did not bring any meaning that can make the students confused. Besides that, based on the data collected, it is also shown that students only show high interest in specific genres of KOMSAS, for example, short stories, and they do not show any interest in other literary materials such as drama, poems or traditional prose. The students feel that they are forced to understand the subject solely for examination purposes and not for interest because they assumed that literature does not have any combination in commercial value compared to other subjects. However, based on the result, it showed that the students still insist on having KOMSAS as a part of the Malay language syllabus. They found the subject itself is not stressful as there are many exciting genres, good values and lessons that can be learned. This situation can also be seen in research done by Chew Fong Peng (2009), where the research shows that KOMSAS can educate students of the good values into students despite the different religion, cultures and customs even the result gathered from the research is not in sync with the students' perspectives. Based on his findings, KOMSAS does not directly portray the reality of Malaysia society and does not implement the elements of unification, which seems to clash with the perspective of respondents of this study because there are KOMSAS materials that have elements of unity and can be the example for the students such as short stories from form four KOMSAS that is 'Memori Seorang Tua,' 'Melissa' and 'Biarkan Samudera.'

The gathered data from the study also show that the highest mean recorded is $4.01(\mathrm{SD}=.54)$ for students who agreed that they should be exposed to many literary materials to master the KOMSAS in the Malay language. Therefore, the researcher agrees with the execution of KOMSAS in the Malay language syllabus, as insisted by the Ministry of Education in Malaysia is in a perfect time. However, there are still many problems faced by both teachers and students, which need to be solved as soon as possible.

In this study, it can also be seen that teachers rarely use the bestari based teaching aids as the mean level is at the medium level, which is $3.26(\mathrm{SD}=.87)$. Hence, the schools have prepared sufficient material for teaching purposes. Teachers need to use them while teaching to attract students' interests in the classroom, such as pictures in comic concepts. The source of media used by the teachers must be attractive to make them think creatively and change their dull perceptions of learning KOMSAS.

The teachers' creativity in using KOMSAS materials in the teaching and learning process also plays an important role. This study shows that the teachers use many creative techniques to teach KOMSAS as it is easier for the students to understand them in classrooms. The data gathered showed a high mean level for teachers' strategizing on the KOMSAS modules used in classrooms, which is $3.76(\mathrm{SD}=.77)$. Simultaneously, group works and activities such as acting and role-play are also used by teachers to attract students. It shows that the teachers are enthusiastic about creating creative teaching techniques, simple and efficiently executed. By implementing these approaches, the students will show a higher interest in classrooms, and the teaching process will be easier. Guidance and encouragement from teachers are also necessary because the students need support to be involved in activities in the classroom.

The research findings also show that the teachers reached a medium mean level for creating creative teaching materials for KOMSAS, which is $3.24(\mathrm{SD}=.88)$. Teachers that teaching KOMSAS need to be aware of the students' interests and needs, creatively and actively participating students in the classroom, and bring up the classrooms to a higher level by exposing the students to high-order thinking skills. Teachers also need to be able to change their way of teaching so that students can be able to participate actively in classrooms, give difficult questions, and also to support the students for changes in avoiding the classroom to be the static state and too one-sided. Therefore, this research also found that 
teachers lack sensitivity in choosing an effective strategy and suitable activity. Therefore, teachers need to integrate their activities and the students' ability, such as explaining to them beforehand about the topic to make sure that they understand it correctly first.

One of the problems that arise during the KOMSAS teaching process is that students are not interested because the teachers' method of teaching is not interesting. The respondents agreed that teachers are not able to use many teaching aids, and thus rely more on textbooks and only give simple comments due to time constraints and the pressure to finish the syllabus. Hence, the teachers and the teaching techniques are the crucial aspects of teaching literature. Good teaching can change the student's perception of a subject. However, the study also shows that the teachers use bestari method instead of the 'Chalk \& Talk' method, but it also seems that the students are still not interested. The research findings also show that the teaching and learning process of KOMSAS in the classroom has a high mean level of $3.89(\mathrm{SD}=.46)$. The KOMSAS texts are to encourage students to make students able to understand the literature text. However, the problem is when the students are given the opportunities to read the text loudly by turns as the teachers are the only one who reads the textbook and explains it in the classroom. With these techniques, the students' participation in the classroom is low, and subsequently, they become bored during the teaching activities. Even the teacher explains the KOMSAS texts in the Mandarin language to improve their understanding, the students fail to show interest in class due to a lack of involvement in giving their opinions in class.

Finally, based on the research findings, it can be seen that there are teachers that give more focus on the examination and the teachers prepared assessment using the examination format without considering the students' level of understanding towards the subject. A high mean value is shown which is $3.90(\mathrm{SD}=.49)$ for the statement that the teachers rely on using activities with examination format due to time constraint which leads them to focus more on the examination aspect. Teaching methods that use examination formats will give a harmful effect on the learning process due to the lack of creative activities where the students are unable to participate and give an active response. This method of teaching method will result in the limitation of students' participation in the classroom, and the most noticeable effect is on the weak students due to being unable to understand correctly the intended learning outcomes.

\section{Conclusion}

The application of KOMSAS materials as a part of form four Malay language subject is aligned with the vision established by the Ministry of Education Malaysia. Even there are some problems faced by the teachers and students in the process of adapting and improving it as making it as a core for the Malay language subject. The study itself has been able to see a small number of the problems that have continuously been occurred since the KOMSAS subject was first introduced in 2000. In reality, there are no perfect methods in teaching and learning KOMSAS that can be done by the teachers to complete their duty in teaching KOMSAS. The teachers need to be smart in adapting the teaching process, which depends on the teachers to create new and make creative activities for the teaching strategies according to the abilities of the students. Even this study not being able to focus more on form four students learning the KOMSAS in the Malay language, the teachers and the Ministry of Education Malaysia need to take into consideration of the particular aspects so that the problems that could affect the students' learning process can be solved in the future. Therefore, it is hoped that this research becomes an idea for the academicians to improve the teaching and learning strategies for KOMSAS.

\section{REFERENCES}

[1] Abdul Rasid Jamian \& Hasmah Ismail. (2013) "Pelaksanaan Pembelajaran Menyeronokkan dalam Pengajaran." Jurnal Pendidikan Bahasa Melayu - JPBM (Malay Language Education Journal - MyLEJ), Universiti Kebangsaan Malaysia. Vol. 3, Bil. 2 (Nov). 49-63.

[2] Abdul Rasid Jamian, Wan Nazira Wan Jaafar, Shamsudin Othman, \& Azhar Md. Sabil (2018), "High-Order Thinking Skill (HOTS) of the Students in Aspect of Understanding Modern Poetry and Prose of Malay Language." International Journal of Academic Research in Business and Social Sciences. Vol. 8, No. 12, Dec, 1044-1058.

[3] Azid, N., Rawian, R., Shaik-Abdullah, S. \& Tee, T.K. (2019). The development of interactive case-based smart thinking and industrial problem-solving stimulator to enhance TVET students' thinking skills. Journal of Engineering Science and Technology, 14(5), 2643-2656.

[4] Chew Fong Peng. (2009). "Pendidikan Sastera Perpaduan Menerusi KOMSAS Tingkatan 4: Pelaksanaan dan Kesannya." Jurnal Pendidikan Malaysia. Universiti Kebangsaan Malaysia. 34 (2): 15-31.

[5] Chew Fong Peng \& Nurmaizah Majelan. (2019). Pelaksanaan Pendidikan Perpaduan Menerusi Teks KOMSAS dalam Kalangan Pelajar Tingkatan 2." Pendeta Journal of Malay Language, Education and Literature. Fakulti Bahasa dan Komunikasi, Universiti Pendidikan Sultan Idris, Jil. 10, 75-90.

[6] Mohd Rashid Md Idris, Jumaardi Saunri, Abdullah Yusuf \& Alimatus Sahrah. (2020). "Lexical "Hujung" in the Philosopyh of Living Bugis in Malaysia." International Journal of Psychosocial Rehabilitation. Vol. 24 (6), 7097-7108.

[7] Noraini Idris. (2010). Penyelidikan dalam Pendidikan. Kuala Lumpur: Mc Graw Hill Malaysia Sdn. Bhd. 
[8] Norfaizah Abdul Jobar, Aireen Aina Bahari, Abdul Rasid Jamian \& Nur Farakhanna Mohd Rusli. (2020). "Aliran Temataik dalam Pendahuluan Penulisan Karangan Murid Bukan Penutur Jati.” Journal of Critical Reviews. Vol. 7 (09), 2210-2222.

[9] Nurhamirah Hashim, Nur Yuhanis Mohd Nasir, Hashim Ismail, Eizah Mat Hussain \& Nurul Syahidah Tahir (2018). "Resepsi Pelajar Terhadap KOMSAS Jendela Menghadap Jalan." Pendeta Journal of Malay Language, Education and Literature. Fakulti Bahasa dan Komunikasi, Universiti Pendidikan Sultan Idris, Jil. 9, 1-15.

[10] Tee, T. K., Saien, S., Rizal, F., Sukardi, Risfendra, Yee, M. H., Mohamad, M. M., Othman, W., Azman, M. N. A. \& Azid, N. (2020). Design and technology teacher in TVET: A view on thinking style and inventive problem-solving skill. Journal of Technical Education and Training, 12 (1),
197-203.

[11] Zamri Mahamod \& Nur Aisyah Mohamad Noor. (2011). "Persepsi Guru tentang Penggunaan Aplikasi Multimedia dalam Pengajaran Komponen Sastera Bahasa Melayu." Gema Online Journal of Language Studies 163, Volume 11(3). Fakulti Pendidikan, Universiti Kebangsaan Malaysia.

[12] Zamri Mahamod \& Jamilah Hassan. (2018). "Persepsi Guru Bahasa Melayu tentang Penggunaan Kaedah Pembelajaran Berasaskan Masalah dalam Pengajaran dan Pemudahcaraan KOMSAS." Pendeta Journal of Malay Language, Education and Literature. Fakulti Bahasa dan Komunikasi, Universiti Pendidikan Sultan Idris, Jil. 9, 41-50.

[13] Zulkifley Hamid. (2005). Penilaian dalam Pengajaran dan Pembelajaran Bahasa Melayu. Kuala Lumpur: Dewan Bahasa dan Pustaka. 